\title{
Analisa Pengaruh Tekanan Air Terhadap Kinerja PLTMH dengan Menggunakan Turbin Archimedes Screw
}

\author{
I Gede Widnyana Putra ${ }^{1}$, Antonius Ibi Weking ${ }^{2}$, Lie Jasa ${ }^{3}$
}

\begin{abstract}
Turbine is the most important component in Micro Hydro Power (MHP). The turbine used in modeling this MHP is Archimedes screw turbine. Archimedes screw turbines are still very scarce to use in Bali. This study aims to facilitate the testing of parameters that affect the performance of the Archimedes screw tubing, one of which is the influence of water pressure. In this study, we will discuss the effect of water pressure on the rotation produced by Archimedes screw turbines so that the voltage, current, power generated by the generator can be seen, torque and efficiency in modeling the MHP. Changes in water pressure given are $4 \mathrm{psi}, 8 \mathrm{psi}, 12 \mathrm{psi}, 20 \mathrm{psi}$, and $24 \mathrm{psi}$. The results showed that the increase in water pressure given caused the performance of MHP to increase, where the highest efficiency was obtained at 24 psi, which was $18.1 \%$ and the lowest efficiency was obtained at 8 psi, which was $2.4 \%$, while at 4 psi the generator it cannot rotate, so the efficiency of the MHP modeling system at a pressure of 4 psi does not exist or equal to 0 .
\end{abstract}

Intisari-Turbin merupakan komponen yang terpenting dalam Pembangkit Listrik Tenaga Mikrohidro (PLTMH). Turbin yang digunakan dalam pemodelan PLTMH ini adalah turbin Archimedes screw. Turbin Archimedes screw ini masih sangat langka digunakan di Bali. Penelitian ini bertujuan untuk mempermudah dalam melakukan pengujian yang berhubungan dengan parameter-parameter yang berpengaruh pada kinerja turbin Archimedes screw salah satunya yaitu pengaruh tekanan air. Pada penelitian ini akan membahas mengenai pengaruh tekanan air terhadap putaran yang dihasilkan oleh turbin Archimedes screw sehingga dapat dilihat tegangan, arus, daya yang dihasilkan oleh generator, torsi dan efisiensi pada pemodelan PLTMH. Perubahan tekanan air yang diberikan yaitu sebesar 4 psi, 8 psi, 12 psi, 16 psi, 20 psi, dan 24 psi. Hasil penelitian menunjukan bahwa peningkatan tekanan air yang diberikan menyebabkan kinerja PLTMH semakin meningkat, dimana diperoleh efisiensi tertinggi pada tekanan 24 psi yaitu sebesar 18,1\% dan efisiensi terendah diperoleh pada tekanan 8 psi yaitu sebesar $2,4 \%$, sedangkan pada tekanan 4 psi generator tidak bisa berputar, sehingga efisiensi dari sistem pemodelan PLTMH pada tekanan 4 psi ini tidak ada atau sama dengan 0.

Kata Kunci- Efisiensi, PLTMH, Turbin Archimedes Screw, Tekanan Air

\section{PENDAHULUAN}

Energi listrik merupakan kebutuhan yang sangat penting

\footnotetext{
${ }^{1}$ Mahasiswa, Program Studi Teknik Elektro Fakultas Teknik Universitas Udayana, Banjar Kedungu, Desa Belalang, Kecamatan Kediri, Kabupaten Tabanan, Bali 80361 INDONESIA (tlp:087855607997; e-mail: widnyanaputra1995@gmail.com

${ }^{1,2}$ Dosen, Program Studi Teknik Elektro Fakultas Teknik Universitas Udayana, Jln. Kampus Bukit Jimbaran 80361 INDONESIA (telp: 0361-703315; fax: 0361-7432103315 e-mail: tonv@unud.ac.ide-mail: lieiasa@unud.ac.id
}

dalam segala aktifitas manusia seperti halnya dalam bidang industri, penggunaan alat-alat elektronik, transportasi, dan lain sebagainya. Konsumsi energi akhir di Indonesia didominasi oleh minyak, diikuti oleh gas, batubara. Dengan pertumbuhan konsumsi yang cepat, diperkirakan bahwa tanpa sumber daya energi yang baru dan upaya efisiensi energi, Indonesia dapat menjadi importir minyak murni dalam waktu dekat [1]. Salah satu cara untuk mengatasi hal ini adalah dengan memanfaatkan sumber energi terbarukan yaitu energi air, energi matahari, energi angin, dan biomassa.

Salah satu sumber energi terbarukan yang sangat berpotensi di Indonesia adalah pemanfaatan energi air. Pembangkit listrik energi terbarukan dengan memanfaatkan energi air bisa dibuat dalam skala besar maupun kecil. Mikrohidro atau yang dimaksud dengan Pembangkit Listrik Tenaga Mikrohidro (PLTMH) adalah suatu pembangkit listrik skala kecil yang menggunakan tenaga air sebagai tenaga penggeraknya seperti, saluran irigasi, sungai atau air terjun alam dengan cara memanfaatkan tinggi terjunan (head) dan jumlah debit air.

Salah satu komponen yang terpenting dalam pembangkit listrik mikrohidro adalah turbin. Banyak jenis turbin yang digunakan dalam pembangkit listrik tenaga mikrohidro, salah satunya adalah turbin screw. Turbin Archimedes screw atau sering juga disebut dengan turbin ulir merupakan teknologi yang sejak zaman kuno telah ditemukan dan diterapkan sebagai pompa, dimana pada konstuksinya terdiri dari satu atau beberapa sudu berbentuk heliks yang terpasang pada poros dan berfungsi sebagai bucket bergerak untuk membawa air ke atas. Kemudian seiring dengan kebutuhan pemanfaatan sumber potensi energi air dengan head rendah, penggunaan ulir Archimedes diterapkan sebagai turbin air [2].

Adapun penelitian PLTMH sebelumnya mengenai turbin Archimedes screw dimana turbin Archimedes screw yang digunakan memiliki panjang $100 \mathrm{~cm}$ [3]. Pada penelitian ini akan membahas PLTMH dengan menggunakan turbin Archimedes screw, dimana panjang turbin yang digunakan lebih panjang dari penelitian sebelumnya yaitu $150 \mathrm{~cm}$, sehingga air yang mengalir pada saluran turbin bisa lebih lama untuk memutar turbin dan dapat meningkatkan efisiensi pada turbin. Turbin Archimedes screw ini masih sangat langka digunakan di Bali. Sehingga untuk mendapatkan data-data spesifikasi yang berkaitan dengan turbin Archimedes screw sulit didapatkan, oleh karena itu perlu dibuatkan sebuah pemodelan PLTMH dengan menggunakan turbin Archimedes screw ini, agar dapat dilakukan pengujian yang berhubungan dengan parameter-parameter yang berpengaruh pada kinerja tubin Archimedes screw salah satunya yaitu pengaruh tekanan air. Pada penelitian ini akan membahas mengenai pengaruh tekanan air terhadap putaran yang dihasilkan oleh turbin sehingga dapat dilihat efisiensi, tegangan, arus dan daya yang dihasilkan oleh generator pada pemodelan pembangkit listrik 
tenaga mikro hidro dengan menggunakan turbin Archimedes screw.

\section{Pembangkit Listrik Tenaga Mikrohidro (PLTMH)}

\section{A. Pengertian Pembangkit Listrik Tenaga Mikrohidro}

Mikrohidro atau yang dimaksud dengan Pembangkit Listrik Tenaga Mikrohidro (PLTMH), adalah suatu pembangkit listrik skala kecil yang menggunakan tenaga air sebagai tenaga penggeraknya seperti, saluran irigasi, sungai atau air terjun alam dengan cara memanfaatkan tinggi terjunan (head) dan jumlah debit air. Mikrohidro merupakan sebuah istilah yang terdiri dari kata mikro yang berarti kecil dan hidro yang berarti air. Secara teknis, mikrohidro memiliki tiga komponen utama yaitu air (sebagai sumber energi), turbin dan generator. Mikrohidro mendapatkan energi dari aliran air yang memiliki perbedaan ketinggian tertentu. Pada dasarnya, mikrohidro memanfaatkan energi potensial jatuhan air (head). Semakin tinggi jatuhan air maka semakin besar energi potensial air yang dapat diubah menjadi energi listrik [4].

Prinsip Pembangkit Listrik Tenaga Mikrohidro (PLTMH) yaitu memanfaatkan jumlah debit air yang mengalir pada aliran sungai, air terjun atau irigasi dan memanfaatkan beda ketinggian aliran air. Aliran air yang membentur turbin akan memutar poros dari turbin yang menyebabkan turbin berputar sehingga menghasilkan energi mekanik. Energi mekanik yang dihasilkan kemudian menggerakan generator dan menghasilkan enegi listrik.

\section{B. Turbin Air}

Turbin air adalah turbin dengan media kerja air, secara umum turbin adalah alat mekanik yang terdiri dari poros dan sudu-sudu. Sudu tetap atau stationary blade, tidak ikut berputar bersama poros dan berfungsi mengarahkan aliran fluida. Sedangkan sudu putar atau rotary blade, mengubah arah dan kecepatan aliran fluida sehingga timbul gaya yang memutar poros [5]. Turbin air dibedakan menjadi dua kelompok yaitu turbin implus dan turbin reaksi. Berikut ini merupakan klasifikasi berbagai jenis turbin air yang digunakan dalam pembangkit listrik tenaga air (PLTMH) [6]:

1) Turbin impuls adalah turbin tekanan sama karena aliran air yang keluar dari nosel tekanannya adalah sama dengan tekanan atmosfir sekitarnya. Energi potensial yang dimiliki air dikonversi menjadi energi kinetik dan masuk melalui nosel. Air yang keluar dari nosel yang mempunyai kecepatan tinggi membentur sudu turbin. Setelah membentur sudu arah kecepatan aliran berubah sehingga terjadi perubahan momentum (impulse). Jenis turbin impuls diantaranya yaitu : Turbin Pelton, Turbin Turgo, Turbin Cross Flow.

2) Turbin reaksi adalah turbin reaksi mempunyai profil khusus pada sudu yang menyebabkan terjadinya penurunan tekanan air selama melalui sudu. Perbedaan tekanan ini memberikan gaya pada sudu sehingga runner (bagian turbin yang berputar) dapat berputar. Turbin yang bekerja berdasarkan prinsip ini dikelompokkan sebagai jenis turbin reaksi diantaranya yaitu : Turbin Francis, Turbin Kaplan.

\section{Turbin Archimedes Screw}

Archimedes sekrup adalah salah satu mesin tertua yang masih digunakan dan berfungsi mengangkat air untuk irigasi dan drainase. Turbin ulir berasal dari konsep kuno oleh ahli matematika dan fisika Archimedes (287 - 212 SM). Sekrup Archimedes terdiri dari permukaan heliks yang mengelilingi poros silindris pusat di dalam pipa berongga seperti pada gambar 1. Ketika digunakan sebagai pompa, sekrup biasanya diputar oleh generator atau tenaga kerja manual. Ketika poros berputar, ujung bawah menggulung volume air yang disebut sebagai ember. Air ini akan meluncur ke dalam tabung spiral saat sekrup berputar, sampai akhirnya mengalir keluar dari bagian atas sekrup. Pompa sekrup digunakan terutama untuk mengalirkan air keluar dari tambang atau area lain dari air yang rendah. Palung yang terbuka dan desain keseluruhan sekrup memungkinkan lintasan puing tanpa tersumbat [7].

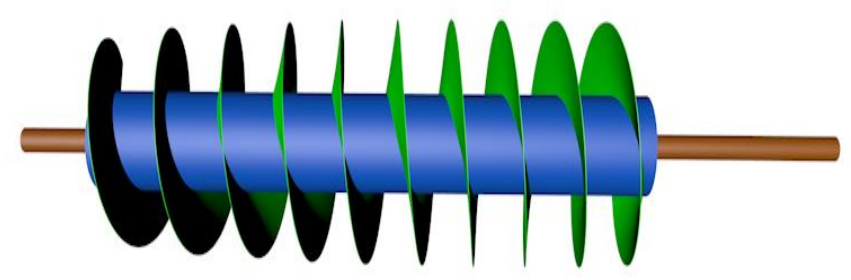

Gambar 1: Turbin Archimedes Screw

Selain dikenal dengan turbin ulir, sesuai dengan konseptor awalnya, turbin ini juga disebut sekrup Archimedes (Archimedes screw). Turbin ulir lebih cocok dipakai untuk tinggi tenaga (head) rendah atau beda elevasi antara hulu dan hilir aliran rendah bahkan nol [8]. Turbin Archimedes screw dapat digunakan di situs hidro air rendah sebagai sarana menghasilkan listrik. Ini dilakukan dengan menjalankan sekrup Archimedes secara terbalik, yaitu menjatuhkan air dari atas dan membiarkan sekrup berputar ketika air turun. Ini adalah cara yang ekonomis dan efisien untuk menghasilkan listrik dari aliran kecil. Sekrup berputar dan menghasilkan listrik karena tekanan hidrostatik dari air pada permukaan sekrup. Saat air mengisi sekrup dari saluran masuk di bagian atas lereng, tekanan pada bidang heliks sekrup memungkinkan untuk rotasi sekrup [9]. Prinsip kerja turbin Archimedes screw ini yaitu, air dari ujung atas mengalir masuk ke ruang di antara kisar blade screw (bucket) dan keluar dari ujung bawah. Sehingga menimbulkan gaya berat air dan beda tekanan hidrostatik dalam bucket di sepanjang rotor mendorong blade screw dan memutar rotor pada sumbunya. Kemudian rotor turbin memutar generator listrik yang disambungkan dengan ujung atas poros turbin screw.

\section{Kelebihan Turbin Archimedes Screw}

Adapun kelebihan yang dimiliki oleh turbin Archimedes Screw dibandingkan dengan jenis turbin lain yaitu sebagai berikut [10] :

1) Baik dikembangkan pada daerah yang memiliki sumber air dengan debit yang cukup besar (sungai) namun hanya memiliki head yang rendah.

2) Tidak memerlukan sistem kontrol yang sangat rumit seperti turbin lainnya. 
3) Tekanan air yang terjadi pada turbin tidak merusak ekologi dalam hal ini dampak terhadap makhluk hidup air (ikan).

4) Tidak membutuhkan draft tube, sehingga dapat mengurangi pengeluaran untuk penggalian pemasangan draft tube.

5) Memiliki efisiensi yang tinggi, dengan variasi debit yang besar dan sangat baik untuk debit air yang kecil.

6) Tidak memerlukan jaring-jaring halus sebagai pencegah masuknya puing-puing kedalam turbin, sehingga dapat mengurangi biaya perawatan.

\section{E. Daya Hidrolis dan Efisiensi}

Debit air adalah besaran yang menyatakan banyaknya air yang mengalir selama satu waktu yang melewati suatu penampang luas. Pengujian debit air bertujuan untuk mengetahui seberapa banyak air yang mengalir dalam satuan volume per satuan waktu [11]. Untuk menghitung nilai debit air, dapat digunakan persamaan sebagai berikut [12]:

$$
\text { Debit }=\frac{\text { Volume bejana }}{\text { Waktu untuk memenuhi bejana }}
$$

Daya hidrolis adalah daya yang dihasilkan oleh air yang mengalir dari suatu ketinggian. Dalam hal ini daya hidrolis diperoleh dari daya air yang dihasilkan oleh pompa [13].

Keterangan :

$$
P=\rho \cdot g \cdot Q \cdot h
$$

$\mathrm{P}=$ Daya hidrolis (Watt)

$\rho=$ Massa jenis fluida/air $\left(\mathrm{kg} / \mathrm{m}^{3}\right)$

$\mathrm{Q}=$ Debit air $\left(\mathrm{m}^{3} / \mathrm{s}\right)$

$\mathrm{g}=$ Gaya gravitasi $\left(\mathrm{m} / \mathrm{s}^{2}\right)$

$\mathrm{H}=$ Head atau tinggi air jatuh $(\mathrm{m})$

Efisiensi sistem (П PLTMH) adalah kemampuan peralatan pembangkit untuk mengubah energi kinetik dari air yang mengalir menjadi energi listrik. Untuk menghitung efisiensi dapat digunakan persamaan sebagai berikut [14] :

$$
\eta_{\text {PLTMH }}=\frac{P_{G}}{P_{H}} \cdot 100 \%
$$

Keterangan :

$\eta_{\text {PLTMH }}=$ Efisiensi sistem PLTMH

$P_{G}=$ Daya Generator

$P_{H}=$ Daya Hidrolis

\section{F. Torsi}

Momen gaya (torsi) adalah sebuah besaran yang menyatakan besarnya gaya yang bekerja pada sebuah benda sehingga mengakibatkan benda tersebut berotasi [15]. Untuk menghitung torsi dapat menggunakan persamaan berikut [16] :

$$
\mathrm{T}=\frac{P}{2 \pi \frac{N}{60}}
$$

Keterangan :

$\mathrm{T}=$ Torsi $(\mathrm{Nm})$

$\mathrm{P}=$ Daya $(\mathrm{kW})$

$\mathrm{N}=$ Kecepatan putaran (rpm)

\section{MATERIAL DAN METODE}

Gambar 2 menunjukan tahapan yang dilakukan pada penelitian ini yaitu mulai dari merancang model sistem PLTMH, menyiapkan bahan serta peralatan, merakit rancangan pemodelan PLTMH, melakukan pengujian PLTMH, mencatat dan menganalisa data

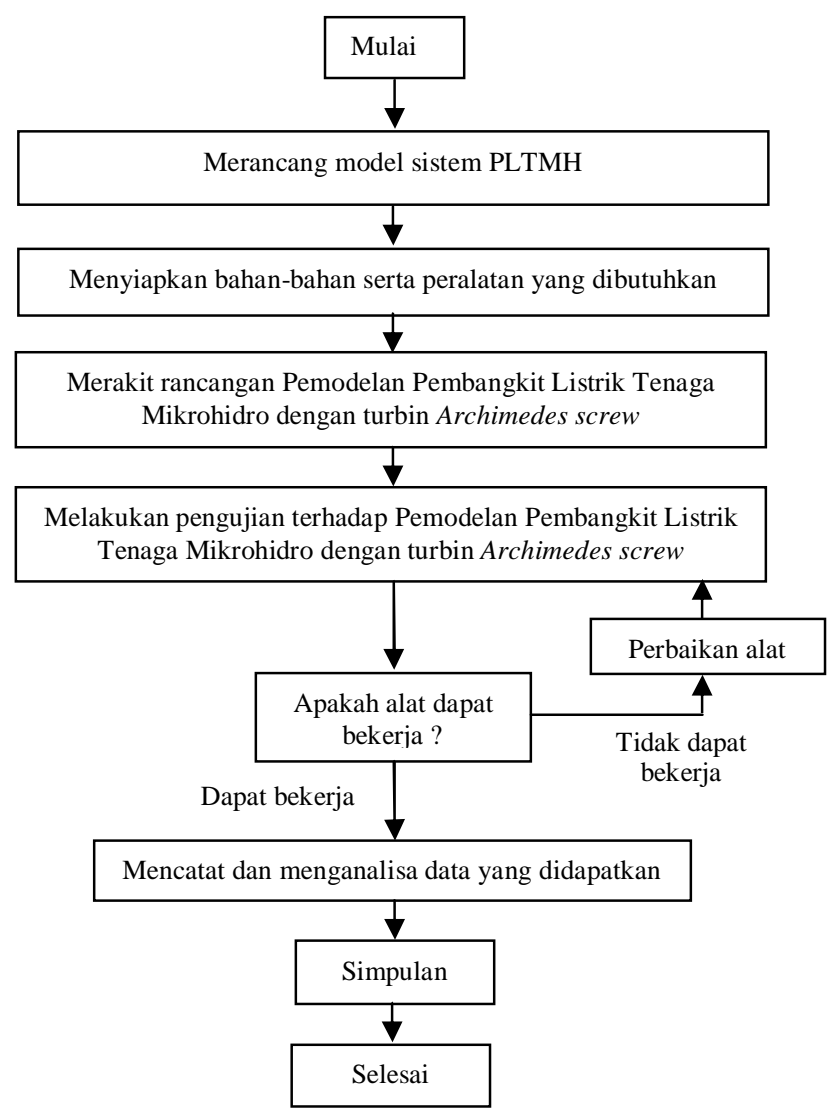

Gambar 2: Alur Penelitian Pemodelan PLTMH

\section{A. Material Pembuatan Rancangan Model Sistem PLTMH}

Perencanaan sistem PLTMH dan spesifikasi turbin yang akan digunakan pada penelitian ini dapat dilihat pada Tabel I dan Tabel II, sedangkan untuk rancangan desain turbin Archimedes screw dapat dilihat pada gambar 3.

TABEL I

PERENCANAAN SISTEM PLTMH

\begin{tabular}{|c|c|}
\hline Parameter & Value \\
\hline Volume Box & 220 liter \\
\hline Head Netto & $134 \mathrm{~cm}$ \\
\hline Panjang rumah turbin & $150 \mathrm{~cm}$ \\
\hline Diameter rumah turbin & $28 \mathrm{~cm}$ \\
\hline Diameter pipa & $7,6 \mathrm{~cm}$ \\
\hline Panjang Pipa Pesat & $300 \mathrm{~cm}$ \\
\hline
\end{tabular}

TABEL II

SPESIFIKASI TURBIN

\begin{tabular}{|c|c|}
\hline Parameter & Value \\
\hline Diameter turbin & $26 \mathrm{~cm}$ \\
\hline Jari-jari turbin & $13 \mathrm{~cm}$ \\
\hline Tebal blade screw & $0,25 \mathrm{~cm}$ \\
\hline
\end{tabular}

p-ISSN:1693 - 2951; e-ISSN: 2503-2372

I Gede Widnyana Putra : Analisa Pengaruh Tekanan Air Terhadap.... 


\begin{tabular}{|c|c|}
\hline Jarak setiap blade screw & $17 \mathrm{~cm}$ \\
\hline Tinggi blade screw & $10 \mathrm{~cm}$ \\
\hline Jumlah blade screw & $1 \mathrm{buah}$ \\
\hline Jumlah lilitan screw & $10 \mathrm{buah}$ \\
\hline Sudut blade screw & $24^{\circ}$ \\
\hline Diameter poros utama & $2,5 \mathrm{~cm}$ \\
\hline Diameter poros luar & $6 \mathrm{~cm}$ \\
\hline Panjang poros utama & $215 \mathrm{~cm}$ \\
\hline Panjang poros luar & $150 \mathrm{~cm}$ \\
\hline Berat turbin & $24 \mathrm{~kg}$ \\
\hline
\end{tabular}

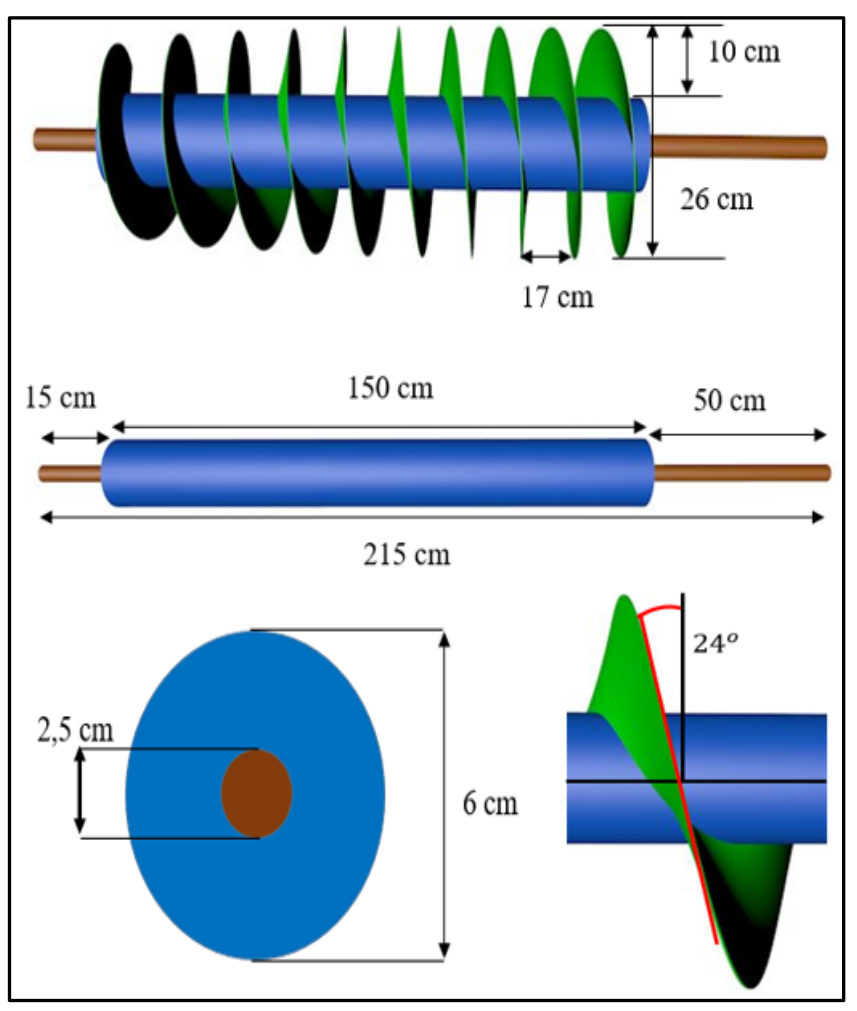

Gambar 3: Rancangan Desain Turbin Archimedes Screw

\section{B. Menyiapkan Alat dan Bahan}

Adapun alat dan bahan yang digunakan dalam pembuatan pemodelan Pembangkit Listrik Tenaga Mikrohidro (PLTMH) dengan menggunakan turbin Archimedes screw ini seperti : box, plat besi, pulley, pillow, pipa, selang air, pompa, dll

\section{Merakit Rancangan Pemodelan PLTMH}

Perakitan rancangan pemodelan PLTMH ini terdiri dari beberapa komponen yaitu turbin Archimedes screw, rangka PLTMH, rumah turbin, pillow, pulley, generator, box, pompa, selang air seperti pada gambar 4.

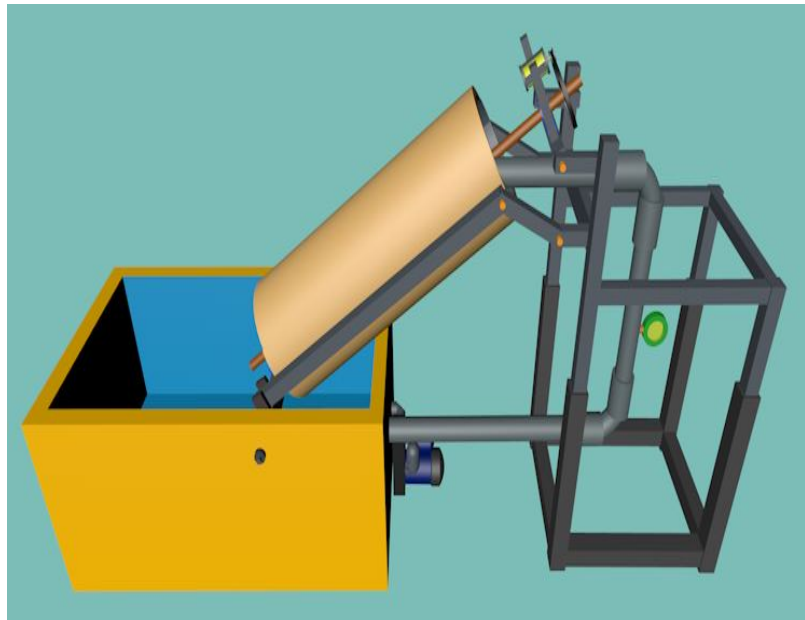

Gambar 4: Rancangan Desain Pemodelan PLTMH

\section{Melakukan Pengujian Pemodelan PLTMH}

Cara kerja pada pengujian pemodelan PLTMH ini yaitu, pertama air yang terdapat dalam box dihisap dengan menggunakan pompa yang terdapat pada box, kemudian air dialirkan ke pipa menuju blade turbin Archimedes screw paling atas. Air dari ujung atas pipa mengalir masuk ke ruang di antara kisar blade screw dan keluar dari ujung bawah. Sehingga menimbulkan gaya berat air dan beda tekanan hidrostatik dalam ruang blade screw sehingga mendorong blade screw disepanjang poros turbin dan memutar poros turbin pada sumbunya. Kemudian pulley yang terdapat pada ujung atas poros turbin memutar generator listrik yang disambungkan dengan pulley pada generator. Pada generator dipasang voltmeter dan amperemeter yang digunakan untuk mengukur tegangan dan arus yang dihasilkan generator. Alat manometer dipasang pada pipa untuk mengukur tekanan air sedangkan tachometer digunakan untuk mengukur putaran generator dan turbin.

\section{E. Mencatat dan Menganalisa Data}

Setelah dilakukan pengujian pada alat yang dibuat, maka akan didapatkan data-data hasil pengujian meliputi data tekanan air, debit air, tegangan, arus, daya, kecepatan putaran turbin dan kecepatan putaran generator yang kemudian akan dianalisis dan digunakan untuk menjelaskan pengaruh tekanan air terhadap torsi dan kecepatan putaran pada generator dan turbin Archimedes screw, pengaruh tekanan air terhadap tegangan, arus dan daya yang dihasilkan oleh generator dengan menggunakan turbin Archimedes screw dan pengaruh tekanan air terhadap efisiensi pada pemodelan PLTMH dengan menggunakan turbin Archimedes screw. Analisis data dalam penelitian ini menggunakan data kuantitatif. Data kuantitatif dalam penelitian ini yaitu diperoleh dari hasil setiap pengujian dimana dilakukan pengujian sebanyak 5 kali pengukuran setiap parameter agar mendapatkan hasil yang akurat dengan tekanan air yang berbeda-beda yaitu tekanan 4 psi, 8 psi, 12 psi, 16 psi, 20 psi dan 24 psi.

\section{IV.HASIL DAN PEMBAHASAN}

\section{A. Realisasi Pemodelan PLTMH}

Realisasi pemodelan Pembangkit Listrik Tenaga Mikrohidro dengan menggunakan turbin Archimedes Screw 
dapat dilihat pada gambar 5, dimana pada pemodelan PLTMH ini terdapat beberapa komponen diantaranya yaitu : turbin Archimedes Screw, pillow yang berfungsi untuk menopang turbin, generator, box yang berfungsi untuk menampung air, pipa yang berfungsi untuk mengalirkan air, pulley yang berfungsi untuk menghubungkan turbin Archimedes screw dengan generator, pompa yang berfungsi mengatur keluar masuknya air yang mengalir melalui pipa, manometer, rumah turbin dan rangka pemodelan PLTMH.

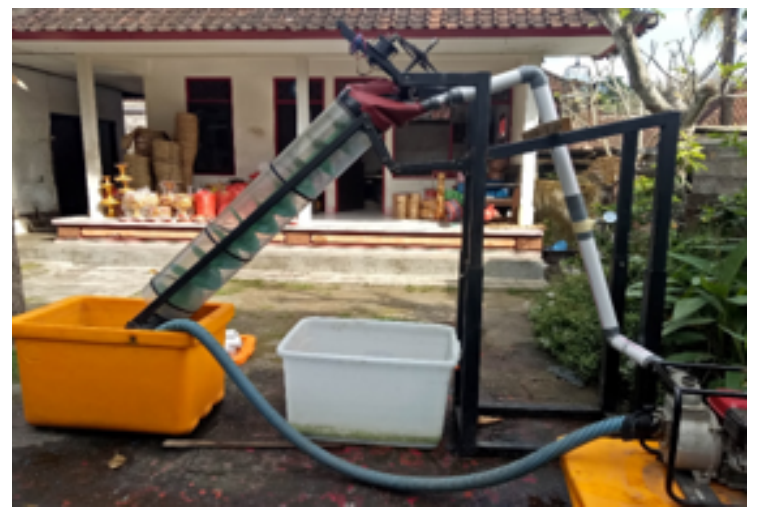

Gambar 5: Realisasi Pemodelan PLTMH

\section{B. Pengukuran Debit Air}

Pengukuran debit air menggunakan metode penampungan air, dalam mengukur debit air menggunakan bak atau box penampungan air yang berkapasitas 220 liter. Pengukuran debit air ini disesuaikan dengan pengaturan tekanan air yang diberikan. Pengujian debit air bertujuan untuk mengetahui seberapa banyak air yang mengalir dalam satuan volume per satuan waktu.

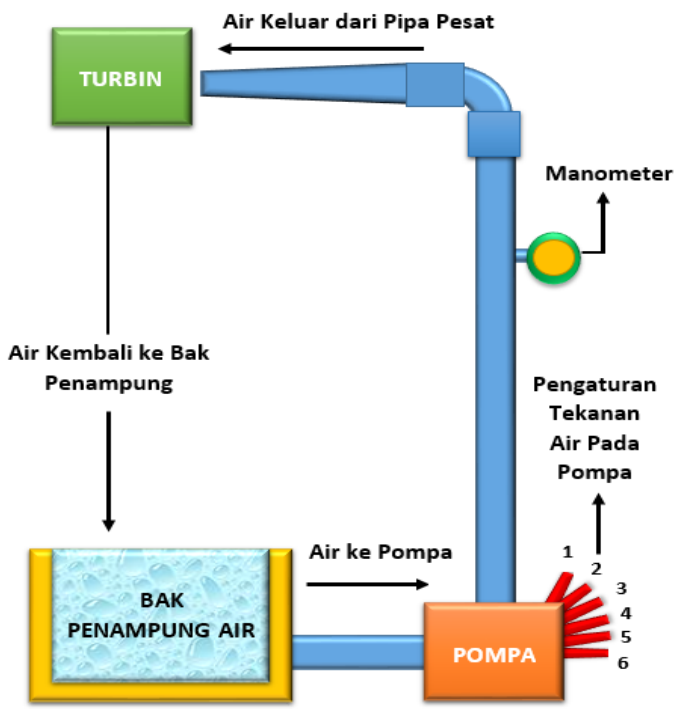

Gambar 6: Sistem Pengaturan Tekanan Air

Gambar 6 merupakan sistem pengaturan tekanan air pada pemodelan pembangkit listrik tenaga mikro hidro ini. Pompa yang digunakan pada pemodelan PLTMH ini memiliki tekanan antara 0 psi sampai 24 psi. Dalam pengaturan tekanan air ini ada 6 posisi pengaturan pada pompa, dimana pada posisi 1 menghasilkan tekanan air 4 psi, pada posisi 2 menghasilkan tekanan air 8 psi, pada posisi 3 menghasilkan tekanan air 12 psi, pada posisi 4 menghasilkan tekanan air 16 psi, pada posisi 5 menghasilkan tekanan air 20 psi dan pada posisi 6 menghasilkan tekanan air 24 psi. Berikut grafik hubungan antara tekanan air dengan debit air :

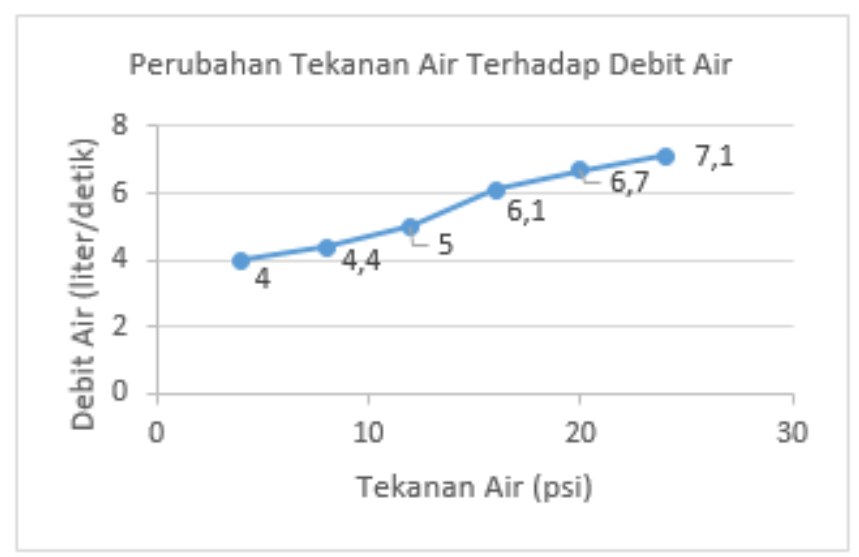

Gambar 7: Grafik Perubahan Tekanan Air Terhadap Debit

Berdasarkan gambar 7 dapat diketahui bahwa debit air semakin meningkat seiring dengan peningkatan tekanan air. Semakin besar tekanan yang diberikan gaya dorong dari aliran air akan semakin besar dan kecepatan air semakin meningkat sehingga debit air semakin besar. Debit air tertinggi saat tekanan air 24 psi yaitu sebesar 7,1 liter/detik, sementara debit air yang terendah terjadi saat tekanan air 4 psi yaitu sebesar 4 liter/detik. Dalam mengukur debit air menggunakan metode penampungan air.

\section{Pengukuran Putaran Turbin}

Grafik hasil pengukuran perubahan tekanan air terhadap putaran turbin dapat dilihat pada gambar 8:

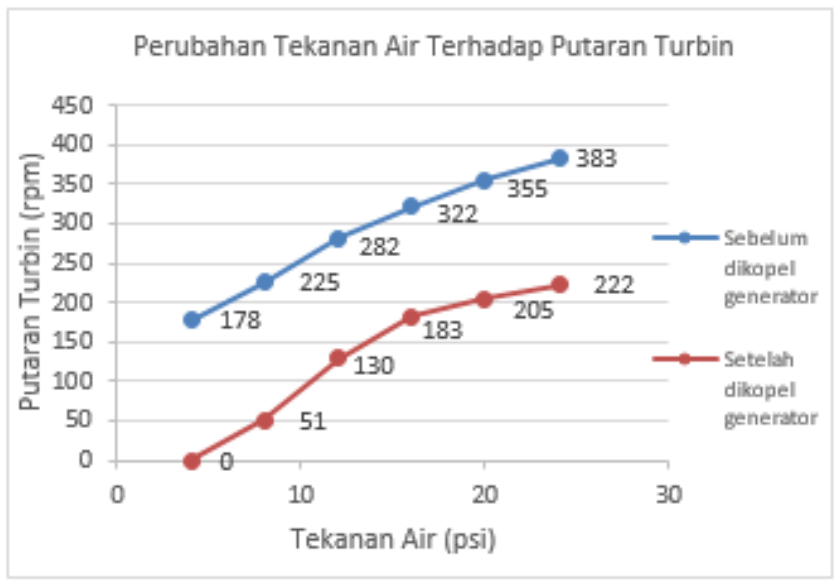

Gambar 8: Grafik Perubahan Tekanan Air Terhadap Putaran Turbin

Berdasarkan gambar 8 dapat dilihat bahwa peningkatan tekanan air yang diberikan akan menyebabkan turbin semakin cepat berputar, hal ini disebabkan semakin besar gaya dorong aliran air yang keluar dari pipa pesat yang kemudian mengenai turbin. Saat turbin dikopel dengan generator kecepatan turbin menjadi menurun, hal ini disebabkan karena turbin mendapatkan beban kerja untuk memutar generator. Kecepatan putaran turbin tertinggi sebelum dikopel dengan generator terjadi saat tekanan air 24 psi yaitu sebesar $383 \mathrm{rpm}$. I Gede Widnyana Putra : Analisa Pengaruh Tekanan Air Terhadap.... 
Sedangkan kecepatan putaran turbin terendah sebelum dikopel dengan generator terjadi saat tekanan air 4 psi yaitu sebesar $178 \mathrm{rpm}$. Kecepatan putaran turbin tertinggi setelah dikopel dengan generator terjadi saat tekanan air 24 psi yaitu sebesar $222 \mathrm{rpm}$. Sedangkan kecepatan putaran turbin terendah setelah dikopel dengan generator terjadi saat tekanan air 8 psi yaitu sebesar $51 \mathrm{rpm}$. Setelah dikopel dengan generator pada tekanan 4 psi turbin tidak bisa berputar hal ini disebabkan oleh beban kerja untuk memutar generator lebih besar dari tekanan air untuk memutar turbin.

\section{Pengukuran Putaran Generator}

Grafik hasil pengukuran perubahan tekanan air terhadap putaran generator dapat dilihat pada gambar 9:

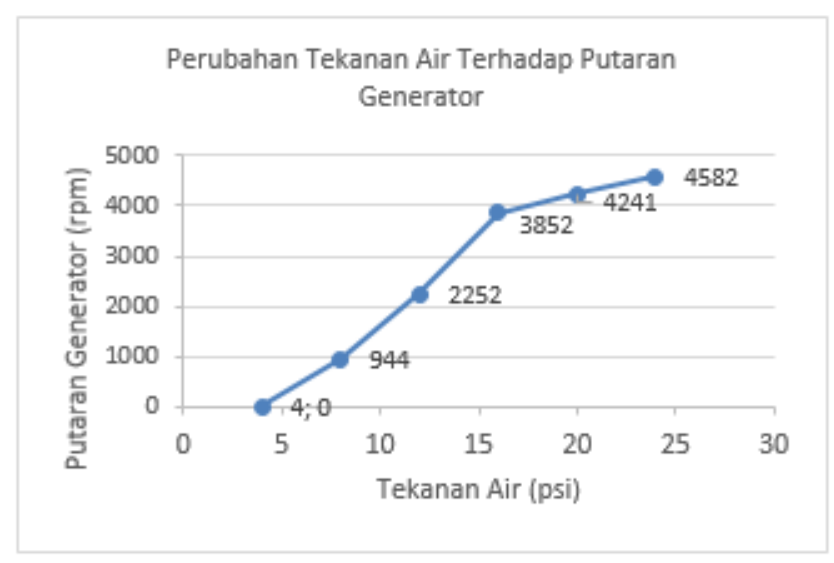

Gambar 9: Grafik Perubahan Tekanan Air Terhadap Putaran Generator

Berdasarkan gambar 9 dapat dilihat bahwa kecepatan putaran generator tertinggi terjadi saat tekanan air 24 psi yaitu sebesar $4582 \mathrm{rpm}$. Sedangkan kecepatan putaran generator terendah terjadi saat tekanan air 8 psi yaitu sebesar $944 \mathrm{rpm}$. Pada saat generator dikopel dengan turbin pada tekanan 4 psi, generator tidak bisa berputar hal ini disebabkan oleh beban kerja untuk memutar generator lebih besar dari tekanan air untuk memutar turbin.

\section{E. Pengukuran Tegangan Generator}

Grafik hasil pengukuran perubahan tekanan air terhadap tegangan generator dapat dilihat pada gambar 10. Berdasarkan gambar 10 dapat dilihat bahwa tegangan generator tertinggi ketika tidak berbeban terjadi saat tekanan air 24 psi yaitu sebesar 119,3 Volt, sementara tegangan yang terendah terjadi saat tekanan air 8 psi yaitu sebesar 29,4 volt. Sedangkan tegangan generator tertinggi saat diberi beban sebesar 60 Watt terjadi saat tekanan 24 psi yaitu sebesar 85,8 volt, sementara tegangan yang terendah terjadi saat 8 psi yaitu sebesar 15,2. Tegangan pada saat keadaan tanpa beban memiliki nilai yang lebih besar, sedangkan tegangan ketika beban 60 Watt mengalami penurunan. Hal ini terjadi karena adanya beban yang diberikan pada generator sehingga tegangannya menjadi menurun. Pada saat generator dikopel dengan turbin pada tekanan 4 psi, generator tidak bisa berputar hal ini disebabkan oleh beban kerja untuk memutar generator lebih besar dari tekanan air untuk memutar turbin sehingga generator tidak bisa menghasilkan tegangan.

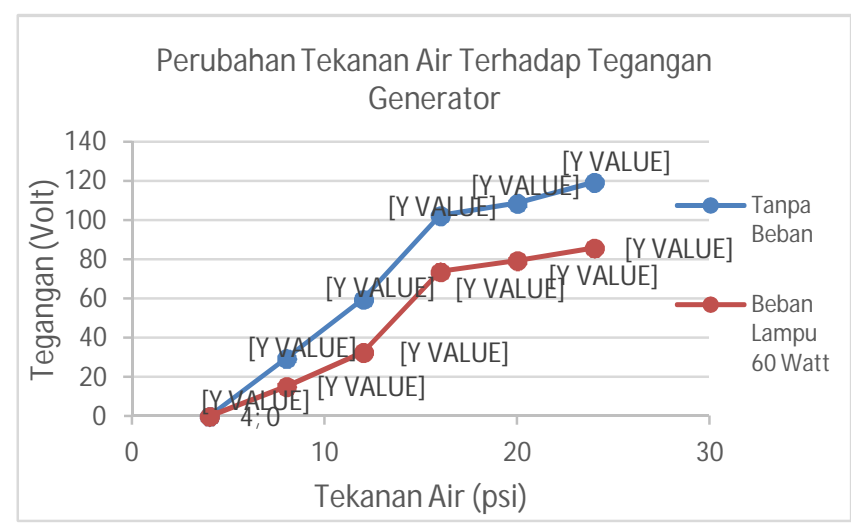

Gambar 10: Grafik Perubahan Tekanan Air Terhadap Tegangan Generator

\section{F. Pengukuran Arus Generator}

Grafik hasil pengukuran perubahan tekanan air terhadap arus generator dapat dilihat pada gambar 11:

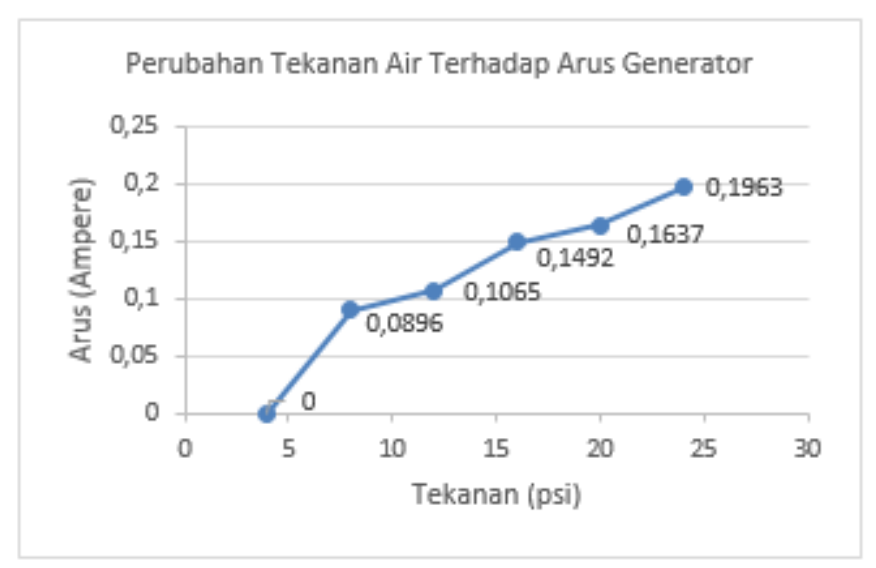

Gambar 11: Grafik Perubahan Tekanan Air Terhadap Arus Generator

Berdasarkan gambar 11 dapat dilihat bahwa arus generator tertinggi terjadi saat tekanan air 24 psi yaitu sebesar 0,1963 Ampere, sementara arus yang terendah terjadi saat tekanan air 8 psi yaitu sebesar 0,0903 Ampere. Pada saat generator dikopel dengan turbin pada tekanan 4 psi, generator tidak bisa berputar hal ini disebabkan oleh beban kerja untuk memutar generator lebih besar dari tekanan air untuk memutar turbin sehingga generator tidak bisa menghasilkan tegangan.

\section{G. Pengukuran Daya Generator}

Grafik hasil pengukuran perubahan tekanan air terhadap daya generator dapat dilihat pada gambar 12:

Perubahan Tekanan Air Terhadap Daya Generator

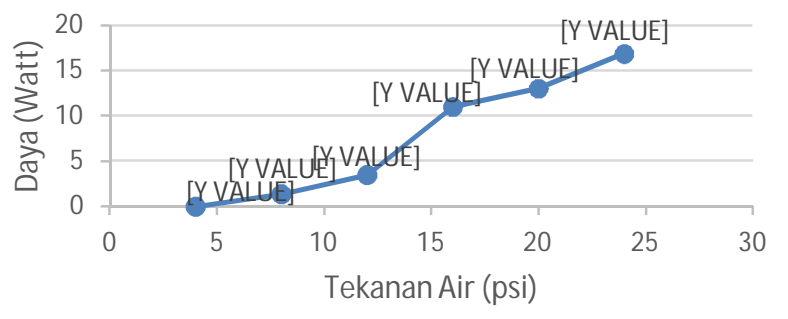

Gambar 12: Grafik Perubahan Tekanan Air Terhadap Daya Generator 
Berdasarkan gambar 12 dapat dilihat bahwa daya tertinggi yang dihasilkan generator terjadi saat tekanan air 24 psi yaitu sebesar 16,85 Watt, sedangkan daya terendah yang dihasilkan generator terjadi saat tekanan air 8 psi yaitu sebesar 1,36 Watt. Pada saat generator dikopel dengan turbin pada tekanan 4 psi, generator tidak bisa berputar hal ini disebabkan oleh beban kerja untuk memutar generator lebih besar dari tekanan air untuk memutar turbin sehingga generator tidak bisa menghasilkan daya.

\section{H. Perhitungan Daya Hidrolis}

Daya hidrolis adalah daya yang dihasilkan oleh air yang mengalir. Dari nilai debit air yang diperoleh sesuai pada gambar 6, maka dapat dihitung daya hidrolis sebagai berikut :

$$
\begin{aligned}
P & =\rho \cdot g \cdot Q \cdot h \\
& =1000 \mathrm{~kg} / \mathrm{m}^{3} \cdot 9,81 \mathrm{~m} / \mathrm{s}^{2} \cdot 0,0040 \mathrm{~m}^{3} / \mathrm{s} .1,34 \mathrm{~m} \\
& =52,6 \text { Watt }
\end{aligned}
$$

Grafik seluruh hasil perhitungan daya hidrolis dapat dilihat pada gambar 13 :

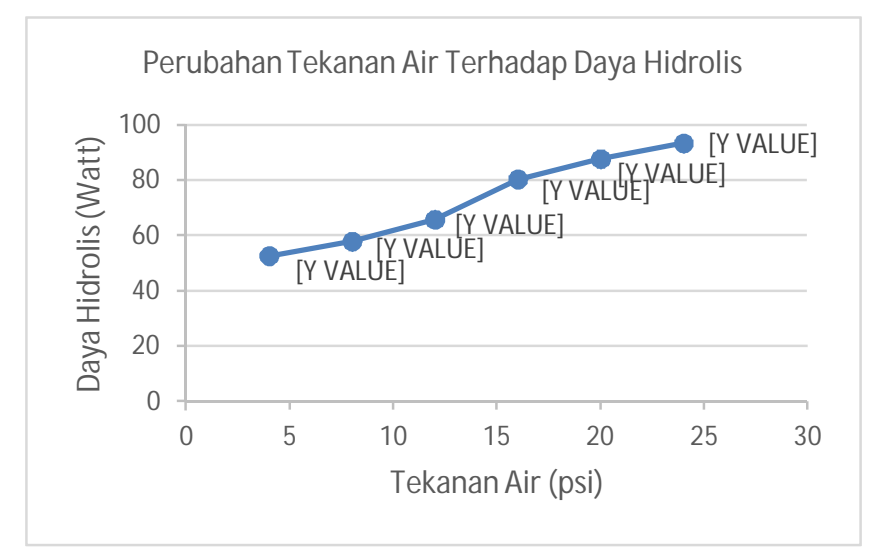

Gambar 13: Grafik Perubahan Tekanan Air Terhadap Daya Hidrolis

Berdasarkan gambar 13 dapat dilihat bahwa peningkatan tekanan air yang diberikan akan menyebabkan daya hidrolis semakin meningkat. Daya hidrolis tertinggi terjadi saat tekanan air 24 psi yaitu sebesar 93,3 Watt, sedangkan daya hidrolis terendah terjadi saat tekanan air 4 psi yaitu sebesar 52,6 Watt.

\section{Perhitungan Efisiensi}

Perhitungan efisiensi diperoleh dari daya output dibagi dengan daya input, maka dapat dihitung efisiensi sebagai berikut :

$$
\eta_{P L T M H}=\frac{P_{G}}{P_{H}} \cdot 100 \%=\frac{1,36}{57,8} \cdot 100 \%=2,4 \%
$$

Grafik hasil perhitungan efisiensi pada pemodelan PLTMH dapat dilihat pada gambar 14 :

I Gede Widnyana Putra : Analisa Pengaruh Tekanan Air Terhadap....

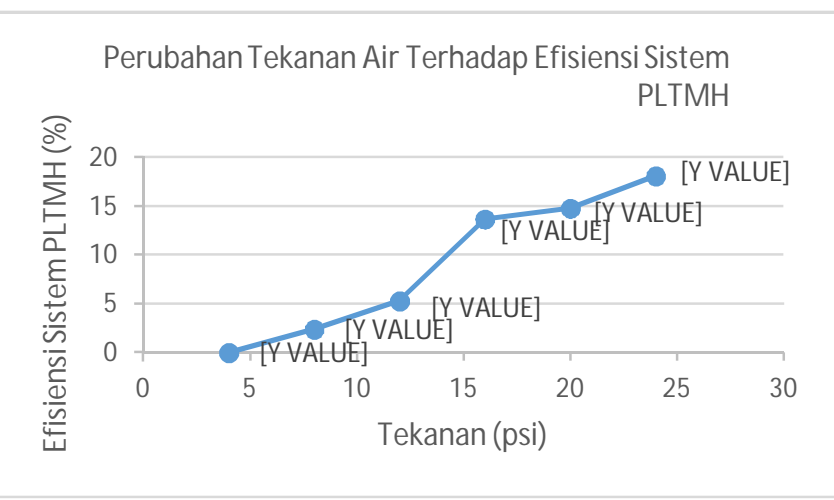

Gambar 14: Perubahan Tekanan Air Terhadap Efisiensi Sistem PLTMH

Berdasarkan gambar 14 dapat dilihat bahwa peningkatan tekanan air yang diberikan akan menyebabkan efisiensi pada sistem PLTMH semakin meningkat. Efisiensi tertinggi terjadi saat tekanan air 24 psi yaitu sebesar $18,1 \%$, sedangkan efisiensi terendah terjadi saat tekanan air 8 psi yaitu sebesar $2,4 \%$. Sedangkan pada tekanan 4 psi generator tidak bisa berputar, sehingga efisiensi dari sistem pemodelan PLTMH pada tekanan 4 psi ini sama dengan 0 .

\section{J. Perhitungan Torsi}

Nilai kecepatan putaran turbin yang diperoleh setelah dikopel dengan generator sesuai pada gambar 8, maka torsi dapat dihitung sebagai berikut :

$$
T=\frac{P}{2 \pi \frac{n}{60}}=\frac{1,36}{2 * 3,14 * \frac{51}{60}}=\frac{1,36}{5,34}=0,25 \mathrm{Nm}
$$

Grafik hasil perhitungan torsi pada pemodelan PLTMH dapat dilihat pada gambar 15 :

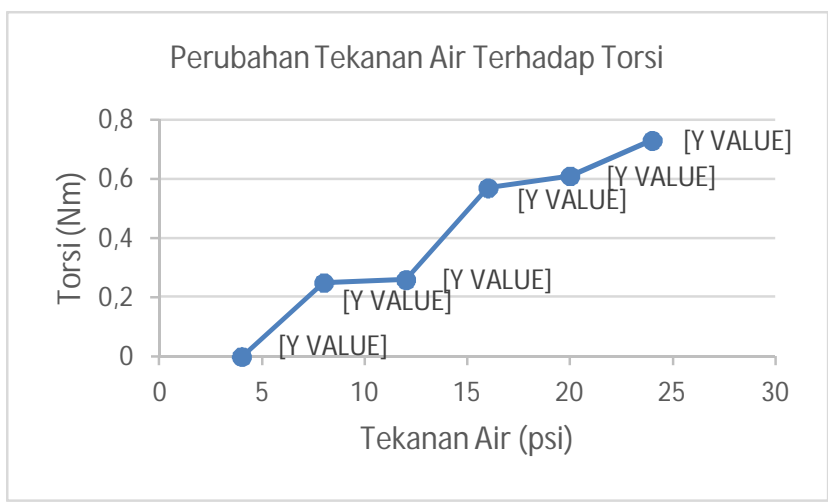

Gambar 15: Grafik Perubahan Tekanan Air Terhadap Torsi

Berdasarkan gambar 15 dapat dilihat bahwa peningkatan tekanan air yang diberikan akan menyebabkan torsi yang dihasilkan semakin meningkat. Torsi tertinggi terjadi saat tekanan air 24 psi yaitu sebesar $0,73 \mathrm{Nm}$, sedangkan torsi terendah terjadi saat tekanan air 8 psi yaitu sebesar $0,25 \mathrm{Nm}$. Sedangkan pada tekanan 4 psi turbin yang dikopel dengan generator tidak bisa berputar, sehingga torsi yang dihasilkan pada tekanan 4 psi ini sama dengan 0. Berdasarkan grafik diatas, maka untuk menghasilkan torsi yang mampu untuk memutar generator agar generator dapat menghasilkan p-ISSN:1693 - 2951; e-ISSN: 2503-2372 
tegangan, arus, dan daya yang besar pada pemodelan PLTMH ini adalah dengan menggunakan tekanan air sebesar 24 psi.

\section{KESIMPULAN}

Simpulan yang dapat diambil berdasarkan hasil dari pengujian dan pembahasan yang telah dilakukan adalah sebagai berikut :

1. Torsi yang dihasilkan pada pengujian pemodelan PLTMH dengan melakukan perubahan peningkatan tekanan air yang diberikan akan menyebabkan torsi yang dihasilkan semakin meningkat. Torsi tertinggi terjadi saat tekanan air 24 psi yaitu sebesar $0,73 \mathrm{Nm}$, sedangkan torsi terendah terjadi saat tekanan air 8 psi yaitu sebesar 0,25 $\mathrm{Nm}$. Sedangkan pada tekanan 4 psi turbin yang dikopel dengan generator tidak bisa berputar, sehingga torsi yang dihasilkan pada tekanan 4 psi ini sama dengan 0 .

2. Pengujian perubahan tekanan air pada pemodelan pembangkit listrik tenaga mikro hidro menggunakan turbin Archimedes screw ini, didapatkan nilai hasil pengukuran terbaik pada tekanan air 24 psi, dimana tegangan, arus, dan daya output yang dihasilkan generator yaitu sebesar 85,8 Volt, 0,1963 Ampere dan 16,85 Watt. Untuk kecepatan putaran generator pada tekanan 24 psi ini yaitu sebesar 4582 rpm, sedangkan kecepatan putaran turbin yang dihasilkan pada tekanan 24 psi ini yaitu sebesar $383 \mathrm{rpm}$ sebelum dikopel dengan generator dan $222 \mathrm{rpm}$ setelah dikopel dengan generator.

3. Efisiensi terbesar yang diperoleh pada pengujian pemodelan PLTMH ini adalah pada tekanan 24 psi yaitu sebesar $18,1 \%$, sedangkan efisiensi terendah terjadi pada tekanan air 8 psi yaitu sebesar 2,4\%. Peningkatan tekanan air yang diberikan akan menyebabkan efisiensi sisem PLTMH semakin meningkat, dimana efisiensi ini dipengaruhi oleh daya hidrolis dan daya generator. Semakin besar tekanan yang diberikan, gaya dorong dari aliran air akan semakin besar dan kecepatan air yang keluar dari pipa pesat semakin meningkat sehingga daya hidrolis akan semakin besar. Daya hidrolis semakin besar menyebabkan daya output generator semakin meningkat sehingga efisiensi pada sistem PLTMH semakin besar.

\section{REFERENSI}

[1] Sitompul, R. 2011. Teknologi Energi Terbarukan Yang Tepat Untuk Aplikasi Di Masyarakat Perdesaan. Jakarta : PNPM Mandiri.

[2] Harja, H.B. Abdurrahim, H. Yoewono, S. Riyanto, H. 2014. Penentuan Dimensi Sudu Turbin dan Sudut Kemiringan Poros Turbin pada Turbin Ulir Archimedes. METAL INDONESIA VOL.36 No.1.

[3] Syahputra, T.M. Syukri, M. Sara, I.D. 2017. Rancang Bangun Prototipe Pembangkit Listrik Tenaga Piko Hydro dengan Menggunakan Turbin Ulir. KITEKTRO: Jurnal Online Teknik Elektro. Vol.2 No.1 2017: 16-22

[4] Apriansyah, F. Rusdinar, A. Darlis, D. 2016. Rancang Bangun Sistem Pembangkit Listrik Mikrohidro (PLTMH) Pada Pipa Saluran
Pembuangan Air Hujan Vertikal. e-Proceeding of Engineering : Vol.3, No.1.

[5] Jasa, L. 2017. Mikro Hidro; Strategi Memanfaatkan Energi Murah dan Ramah Lingkungan. Yogyakarta : Teknosain.

[6] Mafruddin. 2016. "Studi Eksperimental Sudut Nosel dan Sudut Sudu Terhadap Kinerja Turbin Cross-Flow Sebagai PLTMH di Desa Bumi Nabung Timur”. Bandar Lampung : Universitas Lampung.

[7] Songin, K. 2017. "Experimental Analysis of Archimedes Screw Turbines". Canada : University of Guelph.

[8] Setiarso, M.A. Widiyanto, W. Purnomo, S.N. 2016. Potensi Tenaga Listrik dan Penggunaan Turbin Ulir Untuk Pembangkit Skala Kecil di Saluran Irigasi Banjarcahyana. DINAMIKA REKAYASA Vol. 13 No. 1 (2016), Hal. 18-27.

[9] Rorres, C. 2000. The Turn of the Screw: Optimal Design of An Archimedes Screw. Journal of Hydraulic Engineering. Philadelphia.

[10] Saleh, Z. Syafitra, M.F. 2016. Analisis Perbandingan Daya pada Saluran Pembawa untuk Suplai Turbin Ulir Archimedes. Simposium Nasional Teknologi Terapan (SNTT) 4. ISSN : 2339-028X.

[11] Krishnastana, M.A.K. 2017. "Studi Analisis Pengaruh Perubahan Debit Air dan Tekanan Air Pada Pemodelan Pembangkit Listrik Tenaga Mikro Hidro". Bali : Universitas Udayana.

[12] Bahri, A. Jasa, L. Sudarmojo, Y.P. 2017. "Merancang dan Mengimplementasi Modul Praktikum Pembangkit Listrik Tenaga Mikro Hidro di Jurusan Teknik Elektro dan Komputer Universitas Udayana”. Majalah Ilmiah Teknologi Elektro. Vol. 16, No. 02, Mei Agustus 2017.

[13] Tohari, M. 2015. Pengujian Unjuk Kerja Turbin Crossflow Skala Laboratorium dengan Jumlah Sudu 20. Sekolah Tinggi Teknik Harapan.

[14] Sihaloho, D.L. 2017. "Rancang Bangun Alat Uji Model Sistem Pembangkit Listrik Tenaga Mikro Hidro (PLTMH) Menggunakan Turbin Aliran Silang". Bandar Lampung : Universitas Lampung.

[15] Yulistiyanto, B. Hizhar, Y. Lisdiyanti. 2012. Pengaruh Debit Aliran dan Kemiringan Poros Turbin Ulir Pada Pembangkit Listrik Tenaga Mikro-Hidro. Dinamika TEKNIK SIPIL/Vol. 12/No. 1.

[16] Saputra, I.W.B. Weking, A.I, Jasa, L. 2017. "Rancang Bangun Pemodelan Pembangkit Listrik Tenaga Mikro Hidro (PLTMH) Menggunakan Kincir Overshot Wheel". Majalah Ilmiah Teknologi Elektro. Vol. 16, No. 02, Mei-Agustus 2017. 